\title{
PENINGKATAN PEMAHAMAN SISWA TERHADAP TEKS EKSPOSISI DALAM MEDIA MASA MELALUI ADVANCE ORGANIZER DI SMPN
}

\author{
H. Masrik \\ Sekolah Menengah Pertama Negeri 3 Ketapang \\ Email:masrik@gmail.com
}

\begin{abstract}
The object of the authors of this Scientific paper study is based on the fact that students' understanding of the Exposition Text material is still low. In fact, by mastering of Indonesian language in general, the students do not experience difficulties in learning other subjects. This observation was carried out in January to May 2017, because in those months the students had finished the general test and were at the end of the semester so that the condition of the students could be observed from the beginning. The Advance Organizer teaching model is one of the models in the information processing family developed by David Ausubel (1963). From this writing, it can be concluded that the existence of motivation in Advance Organizing learning the ability of students towards Exposition Text material and learning outcomes will be optimal. The more precise the motivation provided, the more successful the lesson will be. With high motivation, the intensity of student learning efforts. It will be able to increase students' understanding of the Exposition Text material in the media through the advance organizer.

Keywords: Improvement, Exposition Text Material, Mass Media, Advance Organizer
\end{abstract}

Keywords: Exposition Text, Mass Media, Through Advance Organizers

\section{PENDAHULUAN}

Setiap kurikulum mengalami perubahan, pihak yang sering dibuat pusing adlah subjek pendidikan, dalam hal nin adalah guru, dan penyelenggara pendidikan, dalam hal ini adalah lembaga pendidikan. Banyak hal yang perlu dibenahi oleh guru dan sekolah, diantaranya adalah cara pandang terhadap proses pembelajaran.

Cara pandang terhadap proses pembelajaran atau bisa dikenal dengan pendekatan pembelajaran yang berpusat kepada guru (teacher centered). Pendekatan ini kemudian terimplementasi kan dalam metode atau cara mengaja guru di kels. Begitu terasa monoton kareena pembelajaran didominasi oleh guru, siswa menjadi pasif karena siswa hanya diberikan informasi secara terua menerus.

Saat ini, dalam kurikulum 2013, guru dituntut untuk lebih inovatif dan kreatif. Pada dasarnya, inovasi dalam pembelajaran diarahkan pada penguasaan materi, media dan menetukan/memilih strategi/model/metode pembelajaran yang tentunya harus disesuaikan dengan maa pelajaran yan akan disampaikan kepada siswa. Dalam pembelajaran bahasa Indonesia diharapkan adanya suatu metode yang dapat meningkatkan keterampilan proses peserta didik untuk memperoleh konsepkonsep bahasa Indonesia, menumbuhkan nilai dan sikap ilmiah serta menerapkan konsep dan prinsip sains untukm menhasilkan suatu karya daat menjadi solusi atas permasalahan yang berkaitan dengan kehidupan manusia. 
Salah satu materi pada pelajaran bahasa indonesia yang dianggap sulit oleh siswa adalah materi Teks Eskposisi dalam media masa. Hal ini pun diperoleh ari hasil pengmatan penulis sekaligus guru kelas dan wawancara dengan siswa kemudian dibuktikan dengan hasil nilai ulangan harian siswa yang hanya mencapai nilai Kriteria Ketuntasan Minimal sekitar 50\%.

Berdasarkan kenyataan tersebut untuk melakukan perbaikan proses belajar men dan hail mata pelajaran bahasa Indno dengan menerapkan metode pembelajaran Advance Organizer. Metode pembelajaraan Advance Organizer memunyai strategi pembelajaran dengan menggunakan masalah/kasus rill di kehidupan sehari-hari sebagai suatu konteks bagis siswa untuk memecahkan masalah dan memperoleh pengetahuan dan konsep yang esensial pada materi Teks Eksposisi dalam media masa. Metode ini memiliki keunggulan dan memiliki ketetapan dalam pembelajaran bahasa Indonesia untuk mencapai standar kompetensi dalam memahami Teks Ekposisi dalam media masa. Metode Advance Organizer merupakan metode pembelajaran yang dapat mendorong siswa untuk melaulkukan aktifitas belajar secara aktif.

Dengan menyadari gejala-gejala atau kenyataan tersebut diatas, maka diadakan penelitian dengan judul Peningkatan Pemahaman Siwa TErhadap Materi Teks Eksposisi dalam Media Masa pada Siwa Kelas VIII SMP Negeri 3 Ketapan Melalui Advance Organize .

Pemecahan masalah yang diterapkan dalam penelitian ini adalah dengan menerapkan metode Advane Organizer dapat mendorong siswa untuk melakukan aktifitas belajar secara aktif, meningkatkan minat belajar siswa.

Sesuai dengan permasalahan di atas, penelitian ini bertujuan untuk: (1) Mengetahui peningkatan pemahaman siswa tentang Teks Eksposisi dalam media masa dengan model pembelajaran Advance Organize pada siswa kelas VIII SMPN 3 ketapang. (2) Mengetahui pengaruh metode pembelajaran Advance Organizer terhadap prestasi pelajaran Teks
Eksposisi dalam media masa pada siswa kelas VIII SMPN 3 Ketapang.

Adapun maksud penulis mengadakan penelitian ini diharapkan dapat berguna sebagai: (1) Menambah pengetahuan dan wawasan yang dapat mendorong tercapainya keberhasilan pembelajaran yaitu aktifnya siswa dalam proses pembelajaran. Disamping itu dengan tercapainya hasil Observasi ini dapat dimanfaatkan dan dipraktikkan dalam keseharian yaitu waktu pembelajaran di kelas. (2) diharapkan keikutsertaan dan peran aktif siswa pada pembelajaran, meningkatkan hasil belajar siswa dan menyiapkan siswa untuk dapat menerapkan hasil pembelajaran Bahasa Indonesia yang diterima di sekolah dalam kehidupan sehari-hari.

Pemahaman adalah hasil belajar, misalnya siswa dapat menjelaskan Dengn kalimatnya sendiri atas apa yang dibaca atau didengannya, memberi contoh lain dari yang telah dicontohkan guru dan mengunakan petunjuk penerapan pada kasus lain (Nana Sujana, 2011). Sedangkan menurut ( S. Bloom, 1956 pemahaman (comprehension) adalah kemampuan seseorang untuk mengerti atau memahami sesuatu setelah sesuatu itu diketahui dan diingat. Sementara definisi pemahaman pemahaman menurut Anas Sudijono adalah kemampuan eseorang untuk mengerti, mengetahui atau memahami sesuatu dan dapat melihatnya dari berbagai segi. Siswa dikatakan paham jika siswa tersebut mampu memberikan penjelasan atau uraian yang lebih rinci dengan menggunakan kata-kata sendiri.

Teks ekposisi adalah teks yang berisi paragrap atau karangan yang di dalamnya terkandung sejumlah pengertian dan informasi yang disajikan secara singkat, padat, akurat, dan tentunya mudah untuk dipahami. Bentuk teks eksposisi, terutama di dalam media massa, dapat berupa esai, tajuk rencana (editoral), ataupun tanggapan kritis.

Model mengajar Advance Organizer adalah salah satu model dalam rumpun pemprosesan informasi yang dikembangkan oleh David Ausubel (1963). Tahap-tahap pembelajaran Advance Organizer yaitu: (1) Penyajian Advance o\Organizer, (2) Penyajian 
bahan pelajaran, (3) Penguatan organisasi kognitif.

Pembelajaran aktif dapat ditingkatkan dengan (1) meminta siswa untuk memasokkan tambahan contoh konsep dalam materi pembelajaran baru; (2) meminta siswa untuk menggambarkan bagaimana cara pembelajaran baru dihubungkan dengan aspek pengetahuan mereka atau pengalaman pribadi mereka; (3) meminta siswa untuk memberikan materi secara lisan dan menerjemahkannya ke dalam isitlah mereka sendiri dan kerangka acuan sendiri.

\section{METODE PNELITIAN}

Penelitian ini dirancang untuk dilakukan dalam dua tahapan. Observasi di kelas ini dilakukan dengan tujuan memperbaiki mutu praktik pembelajaran di kelas, yang berfokus pada pembelajaran di kelas dan mengenai halhal yang terjadi di kelas. Observasi adalah suaut upaya untuk mencermati kegiatan belajar sekelompok eserta didik dengan memberikan sebuah tindakan (treatment) yang sengaja dimunculkan.

Sebelum dilaksanakan penulis observasi, motivasi siswa dalam pembelajaran bahasa Indonesia masih rendah. Dari Observasi yang telah penulis lakukan terhadap aktifitas siswa ketika proses pembelajaran berlangsung, siswa yang berperan secara aktif dalam proses pembelajaran itu baik dalam bentuk interaksi antar siswa maupun siswa dengan pengajar, ternayat dari seluruh siswa kelas VIII yang berjumlah 34 orang hanya 17 orang siswa atau $50 \%$ yang tuntas, sedangkan 17 orang siswa atau $50 \%$ lainnya tindak tuntas.

Waktu penulisan observasi yang telah dilakukan pada Tahapan I hingga Tahapan II dari pertengahan bulan Januari hingga akhir bulan Mei 2017, dibantu oleh seorang guru rekan sejawat yang bertindak sebagai observer dan berfungsi sebagai teman diskusi dalam tahap analisa.

Penelitian Tahapan I ini dilaksanakan melalui, (1) perencanaan, (2) pelaksanaan, dan (3) pengamatan, dan (4) analisis dan perencanaan ulang. Penelitian Tahapan II ini dilaksanakan melalui, (1) perencanaan, (2) pelaksanaan, dan (3) pengamatan (obsevasi).
Tahapan I tersebut dapat dirinci sebagai berikut. Pada perencanaan ini kegiatan yang dilakukan meliputi, (1) menyusun dan memepersiapkan instrument pembelajaran berupa RPP dengan kompetensi Teks Eksposisi dalam media masa, (2) menetapkan jadwal pelaksanaan penulis, (3) menentukan 5 kelopok, satu kelompok terdiri atas 6-7 siswa dan (4) mempersiapkan format penilaian, lebar observasi, daftar nama, dan field note.

Pada pelaksanaan ini meliputi, (1) memilih tema yang cukup menarik untuk disampaikan, (2) memperkenalkan Teks Eksposisi dalam media masa pada peserta didik menjelaskan poin-poin kuni atau masalahmasalah pokok yang diangkat, (3) menekankan pada poin-poin tentang materi Teks Eksposisi dalam media masa pada pembelajaran Bahasa Indonesia, dan (4) melanjutkan proses itu selama masih ada waktunya memungkinkan hingga yang ditentukan hbais.

Pada pengamatan (observasi) merupakan kegiatan yang banyak berhubungan dengan lapangan dan pengolahan hasil penelitian. Pengamatan (obsevasi) meliputi, (1) situasi kegiatan belajar mengajar, (3) minat siswa dan (2) kemampuan siswa dalam memahami materi pembelajaran.

Tahapan II tersebut dapat dirincikan sebagai berikut. Pada perencanaan kegiatan yang dilakukan, (1) menyusun dan mempersiapkan instrumen pembelajaran berupa RPP dengan kompetensi Teks Eksposisi dalam media masa, (2) menetap jadwal pelaksanaan penulisan, (3) menentukan 5 kelompok, satu kelompok terdiri atas 6-7 siswa, dan (4) mempersiapkan format penilaian, lembar observasi, daftar nama, dan field note.

Pada pelaksanaan kegiatan yang dilakukan, (1) suasana pembelajaran sudah mengarah kepada pembelajaran metode Advance Organize, (2) peserta didik termotivasi untuk bertanya dan menanggapi suatu presentasi dari guru, (3) suasana pembelajaran yang efektif dan menyenangkan sudah mulai tercipta, dan (4) siswa lebih antusias mengikuti proses belajar mengajar dikelas. 
Adapun pengamatan (observasi) pada kegiatan yang dilakukan, (1) keaktifan siswa, (2) aktifitas guru, dan (3) ketuntasan belajar siswa, analisis evaluasi.

\section{HASIL DAN PEMBAHASAN PENELITIAN \\ Tahapan I}

Data penelitian yang diperoleh adalah data observasi berupa pengamatan terhadap (1) situasi kegiatan belajar mengajar, (2) minat siswa, dan (3) kemampuan siswa dalam memahami materi pelajaran.

Berdasarkan hasil observasi yang dilakukan dalam Tahapan I kegiatan pelaksanaan Observasi dikelas diperoleh data bahwa siswa dala materi Teks Eksposisi dalam media masa mengalami kenaikan, sebelum penulis Observasi dikelas presentasi minat siswa adalah 50\%. Angka tersebut berdasarkan hasil ulangan harian dan hasil Observasi penulis terhadap minat peserta didik dalam proses pembelajaran Bahasa Indonesai.

Hasil observasi aktifitas guru dalam proses pembelajaran pada Tahapan I masih tergolong rendah dengan peroleh skor 25 atau $58,82 \%$ sedang skor idealnya adalah 40 . Hal ini terjadi karena guru lebih banyak membaca sendiri dan kurang memberanikan kesempatan kepada peserta didik untuk melakukan sendiri.

Penguasaan peserta didik terhadap materi pelajaran pun, asih tergolong kurang dari skor ideal 100 skor perolehan rata-ratanya hanya mencapai 69,11 atau sehingga 58,82\%. Namun telah mengalami kenaikkan dari sebelummnya dilaksanakan Observasi dimana hasil pre-test yang rata-ratanya hanya 62,5 mengalami kenaikan menjadi 69,11 pada post-test tahapan 1.

Dari hasil peneitian dari 34 siswa ternyata yang mampu memahami Teks Ekposisi dalam media masa dengan metode Advance Organize sudah mampu sebanyak 20 siswa. Siswa kuranf mampu memahami Teks Eposisi dalam media masa ada 14 orang.

Berdasarkan data hasil pengamatan terhadap pelaksanaan proses pembelajaran pada tahapan I ini kemampuan Bahasa Indonesia siswa secara individu dalam proses pembelajaran masih lemah $(58,82 \%)$ karena memotivasi siswa masih rendah. Hampir semua siswa siswa belum menunjukkan perkembangan kemampuan mamahami materi Teks Eksposisi dan masih belum ada yang memperoleh nilai sangat baik dan kinerja kelompok belum bagus. Semua kelompok belum menunjukkan perkembangan kemampuan memahami materi Teks Eksposisi dalam media masa dengan kategori baik dan sangat baik dan kinerja kelompok belum bagus dan aspek emapti siswa semuanya belum muncul, semua siswa belum mempunyai rsa kebersamaan, menghargai pelajaran, mau berbagi dan menerima masukan dari teman.

Adapun keberhasilan dan kegagalan yang terjadi pada tahapan I yaitu (1) guru belum terbiasa menciptakan suasana pembelajaran yang mengarahkan kepada pendekatan pembelajaran metode Advance Organizer mereka senang dan antusias untuk belajar. Hasl ini bisa dilihat dari hasil observasi terhadap minat siswa dalam proses pembelajaran hanya mencapai $58,82 \%$, (2) sebagian siswa belum terbiasa dengan kondisi belajar dengan menggunakan pembelajaran metode Advance Organizer mereka merasa senang dan antusias untuk beajar. Hal ini bisa dilihat dari oservasi terhadap aktivitas siswa dalam proses pembelajaran hanya mencapai rata-rat $69,11 \%$, (3) hasil evalusai tahapan I mencapai 58,82, (4) masih ada siswa yang belum bisa menyelesaikan tugas dengan waktu yang di tentukan. Hal ini karena siswa tersebut kurang serius dalam belajar dan (5) masih ada siswa yang kurang mampu memahami materi teks eksposisi dalam media masa.

Untuk memeperbaiki kelemahan dan mempertahankan keberhasilan yang telah dicapai pada Tahapan pertama, maka pada pelaksanaan Tahapan ke II yang dapat dibuat perencanaan sebagai berikut, (1) memeberikan motivasi kepada siswa yang mengalami kesulitan, (2) lebih intensif membimbing siswa yang mengalami kesulitan, dan (3) memberikan pengakuan atau penghargaan (reward).

\section{Tahapan II}

Penguasaan peserta didik terhadap materi pelajaran pun, menunjukkan pengingkatan dari skor ideal 100 dengan rata-rata 79,70 
mengalami kenaikkan menjadi 82,35. Hasil ulangan harian setelah menggunakan pembelajaran Advance Organizer jga mengalami pengingkatan yang sangat signifikan, sedangkan sebelumnya hanya $58,82 \%$.

Berdasarkan data hasil pengamatan terhadap pelaksanaan proses pembelajaran pada Tahapan II yaitu (1) kemampuan memahami materi Teks Eksposisi dalam media masa siswa secara individu dalam proses pembelajaran sangat baik $(82,35 \%)$ karena motivasi siswa cukup tinggi, (2) Hampir semua siswa telah menunjukkan perkembangan kemampuan memahami materi Teks Eksposisi dalam media masa dan sudah ada yang memperoleh nilai sangat baik (maksimal) terutama pada aspek komunikasi, kerja sama dan percaya diri, (3) semua kelompok telah menunjukkan perkembangan kemampuan Teks Eksposisi dalam media masa dengan kategori baik dan sangat baik dan kinerja kelompok sudah bagus, (4) aspek empati siswa semuanya telah muncul, semua siswa sudah mempunyai rasa kebersamaan, menghargai orang lain, menghargai pelajaran, maupun berbagai dan menerima masukan dari teman.

Secara individu, sudah $85 \%$, kemampuan Bahasa Indonesia siswa telah berkembang dan sudah menunjukkan peningkatan yang berarti, baik secara kelompok maupun individu.

Tabel I. Rekapitulasi Hasil Tes Formatif Siswa Pada Siklus II

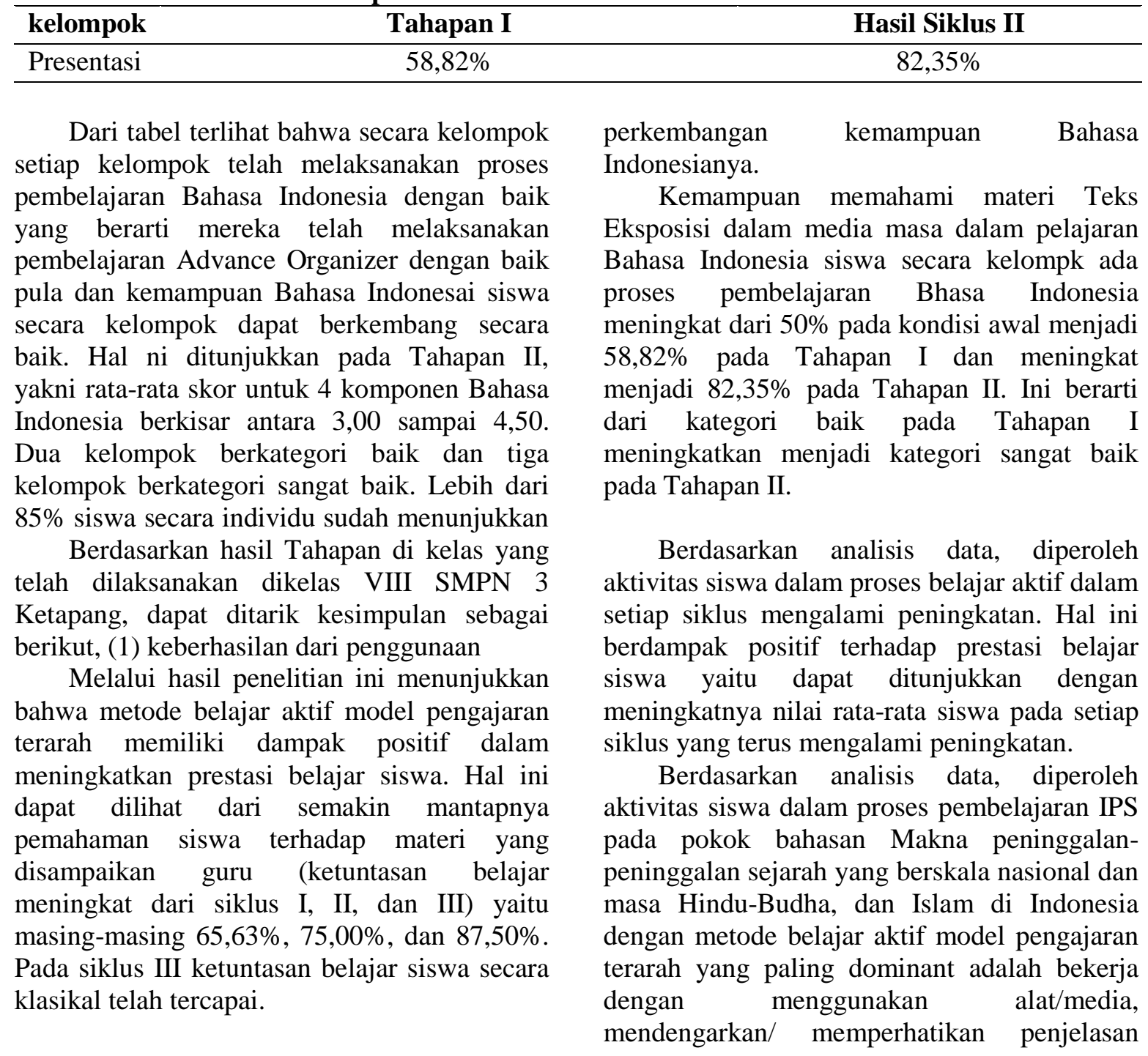


guru, dan diskusi antar siswa/antara siswa dengan guru. Jadi dapat dikatakan bahwa aktivitas isiwa dapat dikategorikan aktif.

Sedangkan untuk aktivitas guru selama pembelajaran telah melaksanakan langkahlangkah belajar aktif dengan baik. Hal ini terlihat dari aktivitas guru yang muncul di antaranya aktivitas membimbing dan mengamati siswa dalam mengerjakan kegiatan LKS/menemukan konsep, menjelaskan materi yang tidak dimengerti, memberi umpan balik/evaluasi/tanya jawab dimana prosentase untuk aktivitas di atas cukup besar.

\section{SIMPULAN DAN SARAN Simpulan}

Dari hasil kegiatan pembelajaran yang telah dilakukan selama tiga siklus, dan berdasarkan seluruh pembahasan serta analisis yang telah dilakukan dapat disimpulkan sebagai berikut: (1) Pembelajaran dengan metode belajar aktif model pengajaran terarah memiliki dampak positif dalam meningkatkan prestasi belajar siswa pada tiap Tahapannya dan (2) Hasil belajar siswa dalam memahami materi Teks Eksposisi dalam media masa secara individu dan kelompok pada proses pembelajaran mata pelajaran Bahasa Indonesia meningkat $50 \%$ pada kondisi awal menjadi $58,82 \%$ pada Tahapan I dan meningkat menjadi $82,35 \%$ pada Tahapan II. Ini berarti dari kategori baik pada Tahapan I meningkat menjadi kategori sangat baik pada Tahapan II.

\section{Saran}

Dalam upaya memperbaiki proses pelaksanaan pembelajaran di sekolah maka dalam kesempatan ini penulis mengajukan beberapa saran yaitu dalam proses pembelajaran, hendaknya guru lebih optimal dalam melaksanakan kegiatan pelajaran sehingga tercipta suasana belajar yang lebih menyenangkan dan penuh semangat.

Guru hendaknya memperhatikan lagu berbagai kelemahan siswa untuk selanjutnya terus memberikan bimbingan yang lebih maksimal dalam proses pembelajaran materi Teks Eksposisi dalam media masa dalam mata pelajaran Bahasa Indonesia.

\section{DAFTAR PUSTAKA}

Bloom, Benjamin S. (1956) Taxonomy of Educational : The Clasification of Educational Goals, Handbook I Cognitive Domain. Newyork: Longmans, Green and Co

Goeleman, D 2002. Working with Emotional Intelligence. New York: Bantam Books.

Lie, Anita. 1995. Adcance Organize mempraktikkan Advance Organizer di ruang-ruang kelas. Jakarta: Grasindo.

Muhammad Nur. 2000. Pembelajaran Advance Organizer. Surabaya: IKIP Surabaya.

Ramadhani. 2008. Bahasa Indonesia dan hard skills. Bandung: PT Remaja Rosdalarya.

Salvin, Robert, E. 1997. Advance Organizer research and practise. Boston: Allyn \& Bacon.

Sudjana, Nana. (2011) . Penilaian Proses Hasil Belajar Mengajar. Bandung: PT Remaja Rosdakarya 